\title{
Extraction/exportation of macronutrients by cladodes of 'Gigante' cactus pear under different spacings and organic fertilization
}

\author{
Paulo E. R. Donato ${ }^{1}$, Sérgio L. R. Donato ${ }^{1}$, João A. Silva ${ }^{1}$, \\ Aureliano J. V. Pires ${ }^{2}$ \& Ancilon A. e Silva Junior ${ }^{1}$ \\ ${ }^{1}$ Instituto Federal de Educação, Ciência e Tecnologia Baiano. Guanambi, BA. E-mail: paulo.donato@guanambi.ifbaiano.edu.br (Correspondig author); \\ sergio.donato@guanambi.ifbaiano.edu.br; joao.silva@guanambi.ifbaiano.edu.br; ancilon.silva@guanambi.ifbaiano.edu.br \\ ${ }^{2}$ Universidade Estadual do Sudoeste da Bahia. Itapetinga, BA. E-mail: aurelianojvp@yahoo.com.br
}

Key words:

Opuntia

nutritional balance

manure

\begin{abstract}
A B S T R A C T
This study aimed to evaluate the extraction/exportation of macronutrients by cladodes of 'Gigante' cactos pear, grown under diferente spacings and doses of cattle manure applied to the soil 600 days after planting. Twelve treatments were used, three spacing $(1.00 \times 0.50$; $2.00 \times 0.25$ and $3.00 \times 1.00 \times 0.25 \mathrm{~m})$ and four doses of cattle manure $(0,30,60$ and 90 $\mathrm{Mg} \mathrm{ha}^{-1}$ year $\left.^{-1}\right)$, arranged in a $3 \mathrm{x} 4$ factorial scheme in randomized blocks, with three replicates. The extraction/exportation of $\mathrm{N}, \mathrm{P}, \mathrm{K}, \mathrm{S}, \mathrm{Ca}$ and $\mathrm{Mg}$ was determined, whose respective values for maximum dry matter production $\left(21.8 \mathrm{Mg} \mathrm{ha}^{-1}\right)$, with a cattle manure dose of $71.8 \mathrm{Mg}$ ha $^{-1}$ year $^{-1}$ were: $287.9,46.2,924.2,40.7,609.7$ and $249.1 \mathrm{~kg} \mathrm{ha}^{-1}, 600$ days after planting. The amounts extracted/exported from N, P, K and Ca varied independently with spacings and manure doses, while $\mathrm{Mg}$ and $\mathrm{S}$ were dependent on the interaction between factors. The doses of manure are insufficient to meet the demand of extracted/exported $\mathrm{K}$, $\mathrm{Ca}$ and $\mathrm{Mg}$. The increments in the doses promote greater nutrient uptake by the plant. The extracted/exported macronutrients in largest amounts are: $\mathrm{K}, \mathrm{Ca}, \mathrm{N}, \mathrm{Mg}, \mathrm{P}$ and $\mathrm{S}$, in this order.
\end{abstract}

\section{Palavras-chave:}

Opuntia

balanço nutricional esterco

\section{Extração/exportação de macronutrientes por cladódios de palma forrageira 'Gigante' sob diferentes espaçamentos e adubação orgânica}

\section{R E S U M O}

Objetivou-se, com este trabalho, avaliar a extração/exportação de macronutrientes por cladódios colhidos da palma forrageira 'Gigante', cultivada sob diferentes espaçamentos e doses de esterco bovino aplicadas ao solo aos 600 dias após o plantio. Foram utilizados 12 tratamentos, três espaçamentos $(1,00 \times 0,50 ; 2,00 \times 0,25$ e 3,00 x 1,00 x 0,25 m) e quatro doses de esterco bovino $\left(0 ; 30 ; 60\right.$ e $90 \mathrm{Mg} \mathrm{ha}^{-1}$ ano $\left.^{-1}\right)$, dispostos em fatorial 3 x 4 num delineamento em blocos casualizados e três repetições. Determinaram-se a extração/exportação de: $\mathrm{N}$, $\mathrm{P}, \mathrm{K}, \mathrm{S}$, Ca e Mg cujos respectivos valores para máxima produção de matéria seca $(21,8$ $\mathrm{Mg} \mathrm{ha}^{-1}$ ), com uma dose de esterco de 71,8 $\mathrm{Mg} \mathrm{ha}^{-1}$ ano $^{-1}$ foram: 287,9; 46,2; 924,2; 40,7; 609,7 e 249,1 kg ha ${ }^{-1}$, aos 600 dias após plantio. As quantidades extraídas de N, P, K e Ca variaram de forma independente com espaçamentos e doses de esterco enquanto as de $\mathrm{Mg}$ e $\mathrm{S}$ foram dependentes da interação entre os fatores. As doses de esterco são insuficientes para atender às quantidades extraídas/exportadas de $\mathrm{K}, \mathrm{Ca}$ e $\mathrm{Mg}$. Os incrementos nas doses promovem maior extração de nutrientes pela planta. Os macronutrientes extraídos/ exportados em maior quantidade são: $\mathrm{K}, \mathrm{Ca}, \mathrm{N}, \mathrm{Mg}, \mathrm{P}$ e S, nesta ordem. 


\section{INTRODUCTION}

Cactus pear (Opuntia ficus-indica) is an indispensable forage support in the semi-arid regions, because it maintains the photosynthetic activity in period of prolonged drought for more than five months (Zañudo-Hernández et al., 2010). Changes in crop management, such as population density, combination of spacings and doses of organic (Donato et al., 2014) or chemical fertilization can interfere with the use of radiation and nutritional status of the plant (Galizzi et al., 2004; Silva et al., 2012), with consequent increment in the photosynthetic rates, growth and yield (Blanco-Macías et al., 2010), and in the extraction/exportation of nutrients. Ramos et al. (2011) concluded that the spacing influences phytomass production and rainfall use efficiency, and the increments are higher for increasing densities (Silva et al., 2014). Donato et al. (2014) observed influence of planting spacings and organic fertilization doses on the morphometric characteristics and dry matter production of cactus pear.

In this crop, harvest removes almost all the vegetative part, leaving no residues for incorporation to the soil, which characterizes a large extraction/exportation. Dubeux Júnior \& Santos (2005) claim that, for a mean biannual dry matter yield of $40 \mathrm{Mg} \mathrm{ha}^{-1}$, the cactus pear extracts approximately $360 \mathrm{~kg}$ $\mathrm{ha}^{-1}$ of N, $64 \mathrm{~kg} \mathrm{ha}^{-1}$ of P, 1,032 $\mathrm{kg} \mathrm{ha}^{-1}$ of $\mathrm{K}$ and $940 \mathrm{~kg} \mathrm{ha}^{-1}$ of $\mathrm{Ca}$. Estimating the amount of nutrients extracted/exported by the plant allows their correct replacement through fertilization, in order to maintain adequate nutrition of the plants and an equilibrated balance of entry and exit of nutrients in the system. Additionally, considering the longevity of the crop, it is concluded that, after 15 years, if the exported nutrients are not replaced over time, the sustainability and resilience of the crop will be compromised, especially in soils of the Brazilian semi-arid region (Fialho et al., 2013).

This study aimed to evaluate the extraction/exportation of macronutrients of 'Gigante' cactus pear, cultivated at different planting spacings and doses of cattle manure applied to the soil.

\section{Material AND Methods}

The experiment was installed in the Federal Institute of Bahia, Campus of Guanambi-BA, Brazil, in September 2009 and continued up to May 2011, in a dystrophic Red Yellow Latosol. The rainfall along the experimental period was 1,393.29, being $611.24 \mathrm{~mm}$ from September 2009 to May 2010 and $782.05 \mathrm{~mm}$ from October 2010 to April 2011 (Donato et al., 2014).

The 12 treatments, four doses of organic fertilization with cattle manure $\left(0,30,60\right.$ and $90 \mathrm{Mg} \mathrm{ha}^{-1}$ year $\left.^{-1}\right)$ and three spacings $(1.00 \times 0.50 ; 2.00 \times 0.25$ and double row $3.00 \times 1.00$ x $0.25 \mathrm{~m}$ ), with 20,000 plants $\mathrm{ha}^{-1}$, were arranged in a $4 \times 3$ factorial scheme in randomized blocks, with three replicates. The total area was $2,304 \mathrm{~m}^{2}$ and the plot area was $64 \mathrm{~m}^{2}(16 \mathrm{x}$ $4 \mathrm{~m})$, with evaluation area of $16 \mathrm{~m}^{2}(8 \times 2 \mathrm{~m})$.

Before soil tillage, samples were collected for chemical analysis: $\mathrm{pH}$ in water $=5.4 ; \mathrm{P}=16.33 \mathrm{mg} \mathrm{dm}^{-3}$ (Extractor: Mehlich-1); $\mathrm{K}=0.29$ (Extractor: Mehlich-1); $\mathrm{Ca}=2.02$ (Extractor: $1 \mathrm{~mol} \mathrm{KCl}$ ); $\mathrm{Mg}=0.90$ (Extractor: $1 \mathrm{~mol} \mathrm{KCl}$ );
$\mathrm{Al}=0.16$ (Extractor: $1 \mathrm{~mol} \mathrm{KCl}) ; \mathrm{H}+\mathrm{Al}=1.69(\mathrm{pH} \mathrm{SMP})$ and $\mathrm{Na}=0.29 \mathrm{cmol} \mathrm{dm}^{-3}$ (Extractor: Mehlich-1); $\mathrm{SB}=3.21 ; \mathrm{t}=$ 3.36 and $\mathrm{T}=5.50$, expressed in $\mathrm{cmol}_{\mathrm{c}} \mathrm{dm}^{-3} ; \mathrm{V}=63.14 \% ; \mathrm{m}=$ 4.86\%; Exchangeable sodium percentage, $\mathrm{ESP}=0.67 \%$; Organic matter $=14.67 \mathrm{~g} \mathrm{dm}^{-3}$ (Colorimetry). Organic fertilization was applied in the furrow, at planting, and repeated one year later in total area. The manure showed the following composition: macronutrients - $\mathrm{Ca}, \mathrm{Mg}, \mathrm{K}, \mathrm{N}$ and $\mathrm{S}-1.7,0.2,2.5,5.2$ and $2.3 \mathrm{~g} \mathrm{~kg}^{-1}$ (EPA $3051 /$ APHA 3120B), in this order, $\mathrm{P}=4.7$ $\mathrm{g} \mathrm{kg}^{-1}$ (APHA 4500-PC), $\mathrm{pH}=7.42$ (Official method - MA) and density $=0.38 \mathrm{~kg} \mathrm{dm}^{-3}$.

Planting was performed with one cladode per hole, vertically buried halfway. The seedlings, with approximate weight of $1.0 \mathrm{~kg}$, free from pests and diseases, after cutting and selection at field, were left at rest in the shade for 15 days, for healing. In May 2011, a sampling was performed for the determination of the contents of nutrients and dry matter. Using a hole saw, 10 samples of $25 \mathrm{~g}$, totaling $250 \mathrm{~g}$ of green matter, were collected in different positions of the plant. The samples were dried in a forced-air oven at $60{ }^{\circ} \mathrm{C}$ for $72 \mathrm{~h}$, then ground in a Wiley-type mill with 1-mm-mesh screen and sent to the laboratory of the Minas Gerais Agricultural Research Company - North (EPAMIG Norte), for the analyses.

The contents of the following nutrients were determined: nitrogen $(\mathrm{N})$, phosphorus $(\mathrm{P})$, potassium $(\mathrm{K})$, sulfur $(\mathrm{S})$, calcium $(\mathrm{Ca})$ and magnesium $(\mathrm{Mg})$, expressed in dag kg-1. The analytical determinations followed the procedures: $\mathrm{N}$, sulfuric acid digestion with the Kjeldahl method; $\mathrm{P}, \mathrm{K}, \mathrm{S}, \mathrm{Ca}$ and $\mathrm{Mg}$, nitric-perchloric acid digestion. The content of dry matter was determined as described by Silva \& Queiroz (2009).

At harvest, three primary cladodes were preserved; after weighing, green matter production was calculated and the dry matter production (DMP) was obtained, as a function of the content of dry matter in the cladodes. The extraction/ exportation of nutrients by cactus pear was calculated based on the DMP of the harvested cladodes and the content of mineral in the cladodes, expressed in $\mathrm{kg} \mathrm{ha}^{-1}$.

The data were subjected to analysis of variance. Tukey test $(p<0.05)$ was used to compare the means of the spacings, while regression analysis was applied for doses of cattle manure and the follow-up analysis of the interactions according to their significance. The regression models were selected based on the adequacy of the studied phenomena, values of determination coefficient and significance of the regression parameters by t-test.

\section{Results AND Discussion}

The amounts of nitrogen, phosphorus, potassium and calcium extracted/exported (NEE, PEE, KEE and CaEE) by the cladodes of 'Gigante' cactus pear varied $(p<0.05)$ independently with the spacings (Table 1) and doses of cattle manure (Figure 1A, B, C, D), with no interactions between the factors. The extraction/exportation of N, P, K and Ca in cladodes of cactus pear varied independently with the spacings (Table 1) and cattle manure doses (Figure 1A, B, C and D), while for $\mathrm{Mg}$ and $\mathrm{S}$ was interaction between spacings and cattle 
Table 1. Amounts of nitrogen (NEE), phosphorus (PEE), potassium (KEE) and calcium (CaEE) extracted/exported $\left(\mathrm{kg} \mathrm{ha}^{-1}\right)$, at $600 \mathrm{DAP}$, in cladodes of 'Gigante' cactus pear cultivated at different spacings

\begin{tabular}{lcccc}
\hline \multirow{2}{*}{ Spacing (m) } & NEE & PEE & \multicolumn{1}{c}{ KEE } & CaEE \\
\cline { 2 - 5 } $1.0 \times 0.5$ & $269.5 \mathrm{a}$ & $40.3 \mathrm{a}$ & $731.6 \mathrm{ab}$ & $611.9 \mathrm{a}$ \\
$2.0 \times 0.25$ & $260.3 \mathrm{~b}$ & $37.5 \mathrm{ab}$ & $821.2 \mathrm{a}$ & $612.9 \mathrm{a}$ \\
$3.0 \times 1.0 \times 0.25$ & $190.6 \mathrm{c}$ & $28.2 \mathrm{~b}$ & $590.7 \mathrm{~b}$ & $418.3 \mathrm{~b}$ \\
Mean & 240.1 & 35.3 & 714.5 & 547.3 \\
CV & 19.7 & 32.5 & 20.9 & 22.1 \\
\hline
\end{tabular}

Means followed by the same letter in the column do not differ significantly by Tukey test at 0.05 probability level. $\mathrm{CV}=$ Coefficient of variation

manure doses (Table 2; Figure $1 \mathrm{E}$ and $\mathrm{F}$ ). The variation for extraction/exportation of nutrients followed the pattern of dry matter production (Donato et al., 2014), with differences only
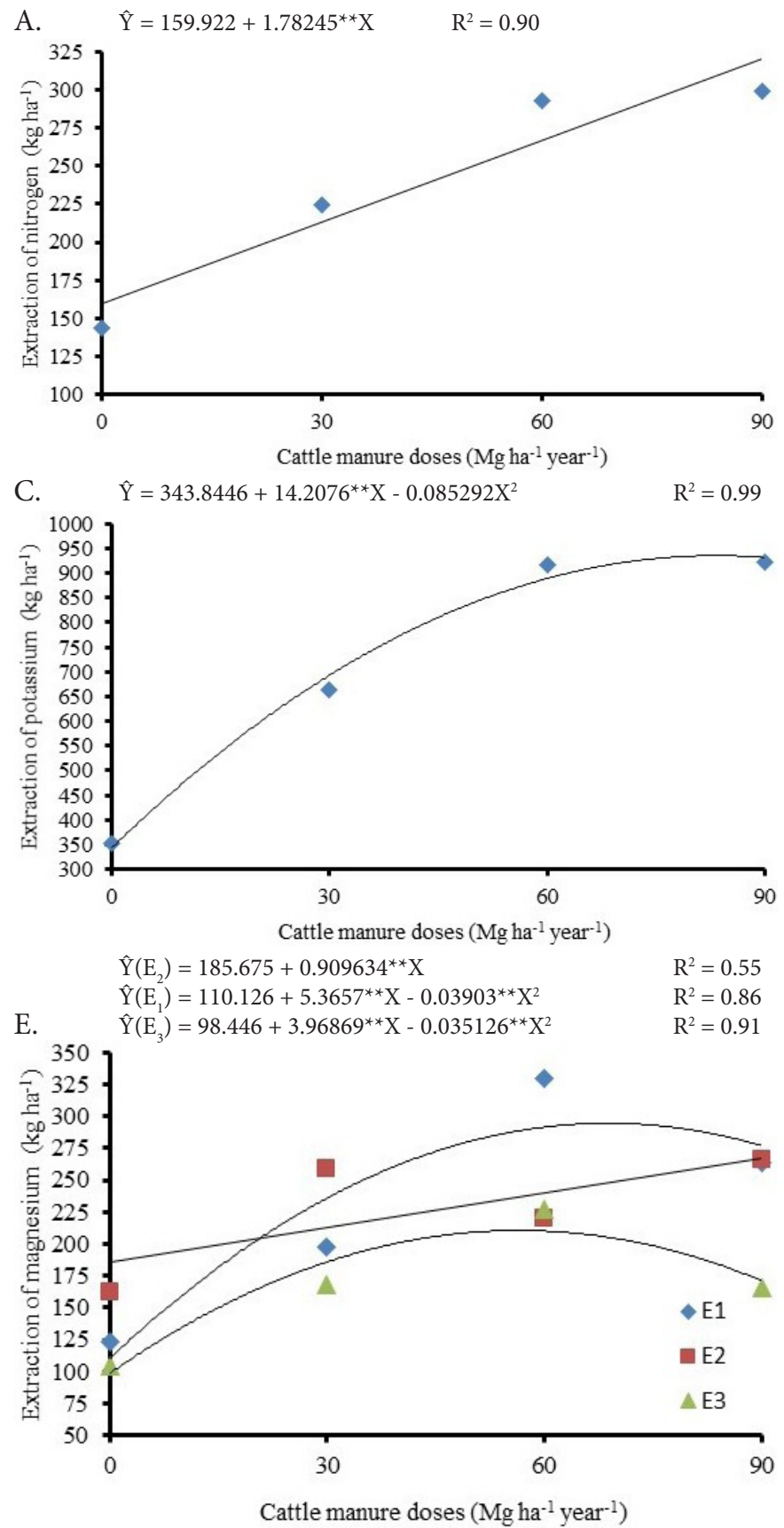

*Significant at 0.05 probability level by t-test; **Significant at 0.01 probability level by t-test function of the cattle manure doses

in the model fitted as a function of the cattle manure doses, quadratic $\left(\hat{y}=11.8874+0.275944^{* *} \mathrm{x}-0.001922^{* *} \mathrm{x}^{2}\right)$, which estimates maximum DMP (21.8 $\left.\mathrm{Mg} \mathrm{ha}^{-1}\right)$ for a cattle manure dose of $71.8 \mathrm{Mg} \mathrm{ha}^{-1}$ year $^{-1}$, in which the respective values of extraction/exportation for $\mathrm{N}, \mathrm{P}, \mathrm{K}, \mathrm{S}, \mathrm{Ca}$ and $\mathrm{Mg}$ were 287.9, $46.2,924.2,40.7,609.7$ and $249.1 \mathrm{~kg} \mathrm{ha}^{-1}$.

The largest amount of NEE was recorded at the spacing of $1.0 \times 0.5 \mathrm{~m}\left(269.5 \mathrm{~kg} \mathrm{ha}^{-1}\right)$, and the lowest one at the spacing of $3.0 \times 1.0 \times 0.25 \mathrm{~m}\left(190.6 \mathrm{~kg} \mathrm{ha}^{-1}\right)$. The cactus pear at the spacing of $2.0 \times 0.25 \mathrm{~m}$ showed intermediate NEE. Greater extraction was observed in the single rows at spacing of $1.0 \times 0.5 \mathrm{~m}$ and the decrease with the increase in the proximity between the plants in the row, as at the spacings of $2.0 \times 0.25$ and $3.0 \times 1.0$ $\mathrm{x} 0.25 \mathrm{~m}$, are justified by the higher competition and yield. For Novais et al. (2007), as the plant population increases or the
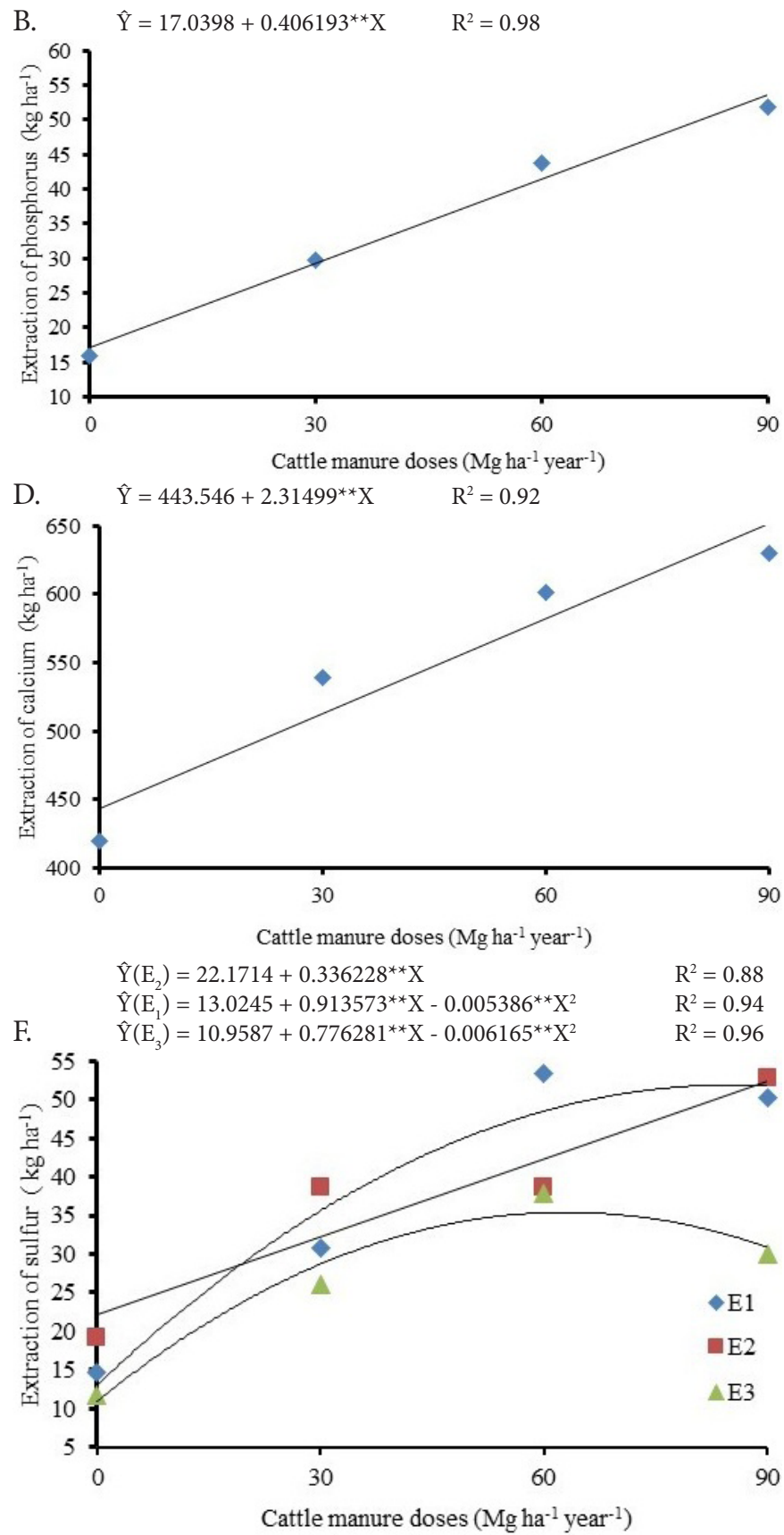

Figure 1. Extraction/exportation of macronutrients in cladodes of 'Gigante' cactus pear at 600 days after planting, as a 
distance between plants decreases, there is an increment in the competition of roots for more mobile nutrients in the soil, such as $\mathrm{N}$, which is transported preferentially through mass flow. The largest amount of NEE occurred at the spacing of 2.0 x $0.25 \mathrm{~m}$, being $140 \mathrm{~kg} \mathrm{ha}^{-1}$ for every $10 \mathrm{Mg} \mathrm{ha}^{-1}$ of dry matter, and the lowest one, $125.6 \mathrm{~kg} \mathrm{ha}^{-1}$, at the spacing of $1.0 \times 0.5 \mathrm{~m}$.

The NEE showed an increasing linear behavior (Figure 1A). The fitted model estimates a variation in the extraction/ exportation from 159.9 to $320.3 \mathrm{~kg} \mathrm{ha}^{-1}$, in response to the increase in the cattle manure dose from 0 to $90 \mathrm{Mg} \mathrm{ha}^{-1}$ year-1. Every $30 \mathrm{Mg} \mathrm{ha}^{-1}$ year $^{-1}$ of manure applied to the soil corresponds, on average, to the $\mathrm{N}$ extraction/exportation of $53 \mathrm{~kg} \mathrm{ha}^{-1}$. On average, the cactus pear extracted/exported $131.6 \mathrm{~kg} \mathrm{ha}^{-1}$ of $\mathrm{N}$ for every $10 \mathrm{Mg} \mathrm{ha}^{-1}$ of DMP. Silva et al. (2016), with chemical fertilization, observed an overall mean extraction/exportation of $177.88 \mathrm{~kg} \mathrm{ha}^{-1}$ of $\mathrm{N}$ for every $10 \mathrm{Mg}$ $\mathrm{ha}^{-1}$ of dry matter. The mean NEE was $240.1 \mathrm{~kg} \mathrm{ha}^{-1}$, which is slightly lower than the value of $299.25 \mathrm{~kg} \mathrm{ha}^{-1}$ found by Silva et al. (2012). Regarding the amount of manure applied to the soil, in the fertilizations at planting and one year later, when 90.0 $\mathrm{Mg} \mathrm{ha}^{-1}$ year $^{-1}$ were applied, the extraction was maximal, reaching the DMP of $21.1 \mathrm{Mg} \mathrm{ha}^{-1}$, which corresponds to 151.8 $\mathrm{kg} \mathrm{ha}^{-1}$ of NEE for every $10 \mathrm{Mg} \mathrm{ha}^{-1}$ of dry matter.

The mean amount of $\mathrm{P}$ extracted/exported (PEE) by the cactus pear was $35.3 \mathrm{~kg} \mathrm{ha}^{-1}$, which is higher than $18.81 \mathrm{~kg}$ $\mathrm{ha}^{-1}$, obtained by Silva et al. (2016). Differences for PEE were observed only between the spacings of $1.0 \times 0.5$ and $3.0 \mathrm{x}$ $1.0 \times 0.25 \mathrm{~m}$, with highest and lowest value, respectively. The amount of PEE in the cladodes of 'Gigante' cactus pear varied linearly with the cattle manure doses (Figure 1B). The greater availability of the nutrient, a consequence of the cattle manure applied to the soil, led to higher extraction, translated into larger exported amount. The addition of manure and other organic sources to the soil reduces the capacity of $\mathrm{P}$ adsorption, increases the available content and promotes greater mobility in the soil profile of soluble organic forms of $\mathrm{P}$. This is more evident for nutrients that are preferentially transported through diffusion, as in this case, because the driving force of this type of transport is the gradient of concentration of the element between the rhizosphere and its surrounding area (Novais et al., 2007). The higher porosity, resulting from the increase of micro- and macro-faunas of the soil, due to the high doses of organic material, also contributes to increasing the diffusive flow of nutrients in the soil, which also promotes, besides the supply of nutrients, the stimulus to the biological activity, potentiating water retention and the formation of aggregates (Nardi et al., 2004). In the treatment without manure application, the amount extracted/exported by the cactus pear was $17 \mathrm{~kg} \mathrm{ha}^{-1}$. For the cattle manure dose of $90 \mathrm{Mg} \mathrm{ha}^{-1}$ year ${ }^{-1}$, the amount of $\mathrm{P}$ was $53.6 \mathrm{~kg} \mathrm{ha}^{-1}$. It is estimated a P extraction/ exportation of $12.2 \mathrm{~kg} \mathrm{ha}^{-1}$ for every $30 \mathrm{Mg} \mathrm{ha}^{-1}$ year $^{-1}$ of manure. Santos et al. (2002) presented data referring to the extraction of $\mathrm{P}$ in cactus pear on the order of $16 \mathrm{~kg} \mathrm{ha}^{-1}$ for every $10 \mathrm{Mg} \mathrm{ha}^{-1}$ of dry matter, a value lower than that observed in the present study, since PEE was, on average, equal to $19.4 \mathrm{~kg} \mathrm{ha}^{-1}$ for every $10 \mathrm{Mg} \mathrm{ha}^{-1}$ of dry matter.
There were differences between the amounts of K extracted/ exported (KEE) by the cladodes of cactus pear cultivated at spacings of $2.0 \times 0.25$ and $3.0 \times 1.0 \times 0.25 \mathrm{~m}$, with highest and lowest value, respectively (Table 1 ). The spacing of $1.0 \mathrm{x}$ $0.5 \mathrm{~m}$ did not differ from $2.0 \times 0.25$ and $3.0 \times 1.0 \times 0.25 \mathrm{~m}$ for the extraction of $\mathrm{K}$. The KEE fitted to a quadratic model as a function of the cattle manure doses (Figure 1C). The model estimates maximum $\mathrm{K}$ extraction/exportation of $935.5 \mathrm{~kg}$ $\mathrm{ha}^{-1}$ when $83.3 \mathrm{Mg} \mathrm{ha}^{-1}$ year $^{-1}$ of manure are applied. The data of Santos et al. (2002) point out that $\mathrm{K}$ is the element most extracted by cactus pear, with value of $258 \mathrm{~kg} \mathrm{ha}^{-1}$ for every $10 \mathrm{Mg} \mathrm{ha}^{-1}$ of dry matter produced. The values of the present study confirm the greater extraction in comparison to the other nutrients. However, they are superior, with mean of $394.5 \mathrm{~kg}$ $\mathrm{ha}^{-1}$ of $\mathrm{K}$ for every $10 \mathrm{Mg} \mathrm{ha}^{-1}$ of dry matter. The mean KEE was $714.5 \mathrm{~kg} \mathrm{ha}^{-1}$, superior to the value of $425.79 \mathrm{~kg} \mathrm{ha}^{-1}$ obtained by Silva et al. (2012), working with chemical fertilization, adding up to $100 \mathrm{~kg} \mathrm{ha}^{-1}$ of $\mathrm{K}_{2} \mathrm{O}$ to the soil.

The amounts of $\mathrm{Ca}$ extracted/exported (CaEE) by the cladodes of cactus pear were similar between the spacings of $1.0 \times 0.5$ and $2.0 \times 0.25 \mathrm{~m}$, which differed from $3.0 \times 1.0 \times 0.25$ $\mathrm{m}$ (Table 1). The observed value (300.7 $\left.\mathrm{kg} \mathrm{ha}^{-1}\right)$ are higher than that reported by Santos et al. (2002), $235 \mathrm{~kg} \mathrm{ha}^{-1}$ for every 10 $\mathrm{Mg} \mathrm{ha}^{-1}$ of dry matter produced. The CaEE increased with the cattle manure doses (Figure 1D). The fitted model estimates the extracted amounts of $443.5 \mathrm{~kg} \mathrm{ha}^{-1}$ without manure and 651.9 $\mathrm{kg} \mathrm{ha}^{-1}$ for the dose of $90 \mathrm{Mg} \mathrm{ha}^{-1}$ year $^{-1}$. The mean CaEE was $547.7 \mathrm{~kg} \mathrm{ha}^{-1}$, superior to the value of $458.28 \mathrm{~kg} \mathrm{ha}^{-1}$ obtained by Silva et al. (2012).

$\mathrm{Ca}$ is the second nutrient most extracted by the cactus pear, only behind $\mathrm{K}$. In general, for $\mathrm{N}$ and $\mathrm{Ca}$, the behavior of extraction/exportation was similar, i.e., these nutrients showed higher extraction/exportation at the single row spacing of 1.0 $\mathrm{x} 0.5 \mathrm{~m}$, in comparison to the double row spacing of $3.0 \times 1.0$ $\mathrm{x} 0.25 \mathrm{~m}$. However, for $\mathrm{P}$ and $\mathrm{K}$, this behavior did not follow the same pattern. The explanations for these facts consider that nutrients with preferential transport through mass flow, such as $\mathrm{N}$ and $\mathrm{Ca}$, suffer greater effect of competition by plant roots, with the increase in plant population or with the decrease in the distance between plants, while for 'immobile' nutrients, transported preferentially through diffusion, such as $\mathrm{P}$, the competition is minimal and occurs only in the cases in which the roots of two neighboring plants come into contact (Novais et al., 2007). K has an intermediate behavior. Its supply to the roots is mainly through mass flow and diffusion, when the amount of nutrients reaching the roots through mass flow and root interception is lower than that absorbed by the plants (Novais et al., 2007).

There were interactions $(\mathrm{p}<0.05)$ between the planting spacings and applied doses of cattle manure, for the amounts of magnesium (MgEE) and sulfur (SEE) extracted/exported by the cladodes of 'Gigante' cactus pear (Table 2, Figure 1E, F).

In the absence of cattle manure and at the dose of $30 \mathrm{Mg}$ $\mathrm{ha}^{-1}$ year $^{-1}$, there was difference for the means of MgEE by the cladodes of 'Gigante' cactus pear cultivated at the three spacings. At the cattle manure dose of $60 \mathrm{Mg} \mathrm{ha}^{-1}$ year $^{-1}$, the $\mathrm{MgEE}$ in the cladodes was similar for the spacings of $2.0 \times 0.25$ 
Table 2. Amounts of magnesium (MgEE) and sulfur (SEE) extracted/exported $\left(\mathrm{kg} \mathrm{ha}^{-1}\right), 600$ days after planting, in cladodes of 'Gigante' cactus pear cultivated at different spacings and cattle manure doses

\begin{tabular}{|c|c|c|c|c|c|}
\hline \multirow{2}{*}{$\begin{array}{l}\text { Spacing } \\
\text { (m) }\end{array}$} & \multicolumn{4}{|c|}{ Cattle manure doses (Mg ha ${ }^{-1}$ year $\left.^{-1}\right)$} & \multirow{2}{*}{ Mean } \\
\hline & 0 & 30 & 60 & 90 & \\
\hline \multicolumn{6}{|c|}{$\operatorname{MgEE}\left(\mathrm{kg} \mathrm{ha}^{-1}\right)$} \\
\hline $1.0 \times 0.5$ & $122.8 \mathrm{~b}$ & $197.8 \mathrm{~b}$ & $329.7 \mathrm{a}$ & $264.2 \mathrm{a}$ & 228.6 \\
\hline $2.0 \times 0.25$ & $162.2 \mathrm{a}$ & $258.4 \mathrm{a}$ & $227.6 \mathrm{~b}$ & $266.2 \mathrm{a}$ & 228.6 \\
\hline $3.0 \times 1.0 \times 0.25$ & $104.2 \mathrm{c}$ & $168.4 \mathrm{c}$ & $219.5 b$ & $165.3 \mathrm{~b}$ & 164.3 \\
\hline Mean & 129.7 & 208.2 & 258.9 & 231.9 & 207.1 \\
\hline CV (\%) & \multicolumn{5}{|c|}{16.4} \\
\hline \multicolumn{6}{|c|}{ SEE $\left(\mathrm{kg} \mathrm{ha}^{-1}\right)$} \\
\hline $1.0 \times 0.5$ & $14.6 \mathrm{a}$ & $30.8 \mathrm{a}$ & $53.3 \mathrm{a}$ & $50.2 \mathrm{a}$ & 37.2 \\
\hline $2.0 \times 0.25$ & $19.1 \mathrm{a}$ & $38.7 \mathrm{a}$ & $38.6 \mathrm{ab}$ & $52.7 \mathrm{a}$ & 37.3 \\
\hline $3.0 \times 1.0 \times 0.25$ & $11.8 \mathrm{a}$ & $26.1 \mathrm{a}$ & $37.9 \mathrm{~b}$ & $30.0 \mathrm{~b}$ & 26.5 \\
\hline Mean & 15.2 & 31.8 & 43.3 & 44.3 & 33.7 \\
\hline CV (\%) & & & 21.3 & & \\
\hline
\end{tabular}

Means followed by the same letter in the column do not differ significantly by Tukey test at 0.05 probability level. $\mathrm{CV}=$ Coefficient of variation

and $3.0 \times 1.0 \times 0.25 \mathrm{~m}$, differing from $1.0 \times 0.5 \mathrm{~m}$. For the cattle manure dose of $90 \mathrm{Mg} \mathrm{ha}^{-1}$ year $^{-1}$, there was no difference of the $\mathrm{MgEE}$ at the spacings of $1.0 \times 0.5$ and $2.0 \times 0.25 \mathrm{~m}$, differing from $3.0 \times 1.0 \times 0.25 \mathrm{~m}$. In general, the $\mathrm{MgEE}$ was higher for the single row spacings, compared with the double row. This result is similar to that reported for $\mathrm{N}$ and $\mathrm{Ca}$, because $\mathrm{Mg}$ also has transport in the soil predominantly through mass flow (Novais et al., 2007); however, there was influence of the cattle manure doses.

The MgEE (Figure 1E) fitted to a quadratic model for the spacings of $1.0 \times 0.5$ and $3.0 \times 1.0 \times 0.25 \mathrm{~m}$, and to a linear model for the spacing of $2.0 \times 0.25 \mathrm{~m}$. The model fitted to the spacing of $1.0 \times 0.5 \mathrm{~m}$ estimates maximum extraction/exportation of $294.5 \mathrm{~kg} \mathrm{ha}^{-1}$ with $68.7 \mathrm{Mg} \mathrm{ha}^{-1}$ year $^{-1}$ of manure. For the spacing of $3.0 \times 1.0 \times 0.25 \mathrm{~m}$, the point of maximum is observed with the application of $56.5 \mathrm{Mg} \mathrm{ha}^{-1}$ year $^{-1}$ of manure, with extraction of $210.5 \mathrm{~kg} \mathrm{ha}^{-1}$ of $\mathrm{Mg}$. For $2.0 \times 0.25 \mathrm{~m}$, the behavior was linear and estimated an extraction/exportation of $27.3 \mathrm{~kg} \mathrm{ha}^{-1}$ of $\mathrm{Mg}$ for every $30 \mathrm{Mg} \mathrm{ha}^{-1}$ year $^{-1}$ of manure applied, by the fitted model. The mean MgEE was $207.1 \mathrm{~kg} \mathrm{ha}^{-1}$, a value close to that found by Silva et al. (2012), $213.75 \mathrm{~kg} \mathrm{ha}^{-1}$.

The highest means of SEE were observed at the spacings of $1.0 \times 0.5$ and $2.0 \times 0.25 \mathrm{~m}, 37.2$ and $37.3 \mathrm{~kg} \mathrm{ha}^{-1}$, respectively, and the lowest one $\left(26.5 \mathrm{~kg} \mathrm{ha}^{-1}\right)$ at $3.0 \times 1.0 \times 0.25 \mathrm{~m}$. The maximum amount of SEE (53.3 kg ha-1) was found for the combination of $1.0 \times 0.5 \mathrm{~m}$ with the cattle manure dose of $60 \mathrm{Mg} \mathrm{ha}^{-1}$ year $^{-1}$ and the lowest one $\left(11.8 \mathrm{~kg} \mathrm{ha}^{-1}\right)$ at $3.0 \times 1.0 \times 0.25 \mathrm{~m}$, without the addition of manure. The mean SEE was $33.7 \mathrm{~kg} \mathrm{ha}^{-1}$, which is lower than the value of $63.27 \mathrm{~kg} \mathrm{ha}^{-1}$ obtained by Silva et al. (2012). The extraction/exportation of S of the cactus pear at the different spacings was similar to that of $\mathrm{N}, \mathrm{Ca}$ and $\mathrm{Mg}$, exclusively at the highest cattle manure dose, $90 \mathrm{Mg} \mathrm{ha}^{-1}$ year $^{-1}$. At this dose, the extraction was higher at the single row spacings, compared with the double row, where there is greater competition. For $\mathrm{S}$, as for $\mathrm{N}, \mathrm{Mg}$ and $\mathrm{Ca}$, nutrients that are more mobile in the soil, the mass flow contributes with greater participation in its transport to plant roots and, therefore, as the plant population increases or the distance between plants decreases, as in the double row spacings, $3.0 \times 1.0 \times 0.25 \mathrm{~m}$, there is an increase in the competition of the roots for these nutrients (Novais et al., 2007) and a reduction in the extraction, although $S$ has lower mobility in the soil, compared with those nutrients, which justifies the similarity of behavior only at the highest cattle manure dose.

The SEE varied quadratically (Figure $1 \mathrm{~F}$ ) for the spacings of $1.0 \times 0.5$ and $3.0 \times 1.0 \times 0.25 \mathrm{~m}$, being linear for the spacing of $2.0 \times 0.25 \mathrm{~m}$. The fitted model estimates that, at the spacing of $1.0 \times 0.5 \mathrm{~m}$, the point of maximum occurs for the application of $85.0 \mathrm{Mg} \mathrm{ha}^{-1}$ year $^{-1}$ of cattle manure, with S extraction of 51.9 $\mathrm{kg} \mathrm{ha}^{-1}$ and, at $3.0 \times 1.0 \times 0.25 \mathrm{~m}$, for the application of 62.9 $\mathrm{Mg} \mathrm{ha}^{-1}$ year $^{-1}$ of cattle manure, with $\mathrm{S}$ extraction of $35.4 \mathrm{~kg} \mathrm{ha}^{-1}$. For the spacing of $2.0 \times 0.25 \mathrm{~m}$, the behavior was linear, with an increment in S extraction/exportation of $10.0 \mathrm{~kg} \mathrm{ha}^{-1}$ for every $30 \mathrm{Mg} \mathrm{ha}^{-1}$ year $^{-1}$ of manure, according to the fitted model.

Among the macronutrients (N, P, K, Ca, Mg and S) extracted/exported by the harvested cladodes of 'Gigante' cactus pear (Table 3), the decreasing order regarding the mean extracted amount was: $\mathrm{K}, \mathrm{Ca}, \mathrm{N}, \mathrm{Mg}, \mathrm{P}$ and $\mathrm{S}$.

These data agree with those of Teles et al. (2004), who worked with cactus pear in greenhouse, but differ from the results of Silva et al. (2016), who reported the following sequence: $\mathrm{Ca}, \mathrm{K}, \mathrm{N}, \mathrm{Mg}, \mathrm{S}$ and $\mathrm{P}$. There was a deficit of $\mathrm{K}, \mathrm{Ca}$ and $\mathrm{Mg}$ in relation to the cattle manure doses applied to the soil. Thus, it is necessary to add these nutrients to maintain a high and sustainable production. Since the balance for these nutrients is negative, it is probable the occurrence of depletion in the production system, not guaranteeing a satisfactory dry matter production, at least for soils of low to medium buffering capacity for these nutrients, as in the present study.

The extraction of $\mathrm{K}, \mathrm{Ca}$ and $\mathrm{Mg}$ was higher than the added amount. This extraction was possible because of the buffering capacity of the soil for these nutrients. For these nutrients, the soil is not a sink and, because of this, the plant does not suffer competition in relation to the soil, because all these elements retained in the exchange complex will replace the nutrients

Table 3. Balance of nutrients (nitrogen, phosphorus, potassium, calcium, magnesium and sulfur) as a function of the mean extraction/exportation by the cladodes of 'Gigante' cactus pear and added to the soil by the cattle manure, 600 days after planting

\begin{tabular}{|c|c|c|c|c|}
\hline & \multicolumn{4}{|c|}{ Dose $\left(\mathrm{Mg} \mathrm{ha}^{-1}\right.$ year $\left.^{-1}\right)$} \\
\hline & 0 & 30 & 60 & 90 \\
\hline Nitrogen Extracted/exported $\left(\mathrm{kg} \mathrm{ha}^{-1}\right)$ & 143.9 & 224.2 & 293.2 & 299.1 \\
\hline Nitrogen added $\left(\mathrm{kg} \mathrm{ha}^{-1}\right)$ & 0.0 & 259.0 & 518.0 & 777.0 \\
\hline Balance of Nitrogen (kg ha-1) & -143.9 & 34.8 & 224.8 & 477.9 \\
\hline Phosphorus Extracted/exported (kg ha $\left.{ }^{-1}\right)$ & 15.9 & 29.3 & 43.8 & 51.8 \\
\hline Phosphorus added (kg ha-1) & 0.0 & 234.0 & 468.0 & 702.0 \\
\hline Balance of Phosphorus (kg ha-1) & -15.9 & 204.7 & 424.2 & 650.2 \\
\hline Potassium Extracted/exported (kg ha-1) & 352.3 & 664.8 & 917.7 & 922.2 \\
\hline Potassium added (kg ha $\left.{ }^{-1}\right)$ & 0.0 & 124.5 & 249.0 & 373.5 \\
\hline Balance of Potassium (kg ha-1) & -352.3 & -540.3 & -668.7 & 548.7 \\
\hline Calcium Extracted/exported $\left(\mathrm{kg} \mathrm{ha}^{-1}\right)$ & 419.8 & 539.0 & 601.0 & 630.0 \\
\hline Calcium added $\left(\mathrm{kg} \mathrm{ha}^{-1}\right)$ & 0.0 & 84.6 & 169.2 & 253.8 \\
\hline Balance of Calcium $\left(\mathrm{kg} \mathrm{ha}^{-1}\right)$ & -419.0 & -454.4 & -431.8 & -376.2 \\
\hline Magnesium Extracted/exported (kg ha-1) & 129.8 & 208.2 & 258.9 & 231.8 \\
\hline Magnesium added $\left(\mathrm{kg} \mathrm{ha}^{-1}\right)$ & 0.0 & 9.9 & 19.9 & 29.8 \\
\hline Balance of Magnesium $\left(\mathrm{kg} \mathrm{ha}^{-1}\right)$ & -129.8 & - 198.3 & - 239.0 & -201.2 \\
\hline Sulfur Extracted/exported $\left(\mathrm{kg} \mathrm{ha}^{-1}\right)$ & 15.2 & 37.1 & 94.7 & 162.7 \\
\hline Sulfur added $\left(\mathrm{kg} \mathrm{ha}^{-1}\right)$ & 0.0 & 114.5 & 229.0 & 343.5 \\
\hline Balance of Sulfur $\left(\mathrm{kg} \mathrm{ha}^{-1}\right)$ & -15.2 & 77.4 & 134.3 & 180.8 \\
\hline Dry matter production $\left(\mathrm{Mg} \mathrm{ha}^{-1}\right)$ & 12.2 & 17.7 & 22.3 & 20.9 \\
\hline
\end{tabular}


removed from the soil solution as they are absorbed by the plant. This occurs because the bonds of these elements with the negative charges of the soil are ionic or electrovalent, with very low energy of adsorption (Novais et al., 2007).

\section{Conclusions}

1. The extracted amounts of N, P, K and Ca in cladodes of cactus pear varied independently with the spacings and cattle manure doses. However, the spacing of $3.0 \times 1.0 \times 0.25 \mathrm{~m}$ promoted the lowest extracted/exported amounts of $\mathrm{N}$ and $\mathrm{Ca}$.

2. There was interaction between spacings and cattle manure doses for $\mathrm{Mg}$ and $\mathrm{S}$ in cladodes of cactus pear and the best means occurred at the doses of 60 and $90 \mathrm{Mg} \mathrm{ha}^{-1}$ year $^{-1}$ for $\mathrm{Mg}$ and $\mathrm{S}$, respectively, at the spacing of $1.0 \times 0.5 \mathrm{~m}$.

3. Cattle manure doses up to $90 \mathrm{Mg} \mathrm{ha}^{-1}$ are insufficient to replace the exported amounts of $\mathrm{K}, \mathrm{Ca}$ and $\mathrm{Mg}$.

4. The increments in cattle manure doses promoted a greater extraction of nutrients and increased their contents in the cladodes of the cactus pear.

5. The decreasing order of extraction/exportation of macronutrients is: $\mathrm{K}, \mathrm{Ca}, \mathrm{N}, \mathrm{Mg}, \mathrm{P}$ and $\mathrm{S}$.

\section{Literature Cited}

Blanco-Macías, F.; Magallanes-Quintanar, R.; Valdez-Cepeda, R. D.; Vázquez-Alvarado, R.; Olivares-Sáenz, E.; Gutiérrez-Ornelas, E.; Vidales-Contreras, J. A.; Murillo-Amador, B. Nutritional reference values for Opuntia ficus-indica determined by means of the boundary-line approach. Journal of Plant Nutrition Soil Science, v.173, p.927-934, 2010. http://dx.doi.org/10.1002/jpln.200900147

Donato, P. E. R.; Pires, A. J. V.; Donato, S. L. R.; Bonomo, P.; Silva, J. A.; Aquino, A. A. Morfometria e rendimento da palma forrageira 'Gigante' sob diferentes espaçamentos e doses de adubação orgânica. Revista Brasileira de Ciências Agrárias, v.9, p.151-158, 2014. http://dx.doi.org/10.5039/agraria.v9i1a3252

Dubeux Júnior, J. C. B.; Santos, M. V. F. Exigências nutricionais da palma forrageira. In: Menezes, R. S. C.; Simões, D. A.; Sampaio, E. V. S. B. (ed.). A palma no Nordeste do Brasil: Conhecimento atual e perspectivas de uso. 2.ed. Recife: UFPE, 2005. p.105-128.

Fialho, J. S.; Aguiar, M. I.; Maia, L. S.; Magalhães, R. B.; Araújo, F. C. S.; Campanha, M. M.; Oliveira, T. S. Soil quality, resistance and resilience in traditional agricultural and agroforestry ecosystems in Brasil's semiarid region. African Journal of Agricultural Research, v.8, p.5020-5031, 2013. http://dx.doi.org/ 10.5897/ AJAR2013.6712
Galizzi, F. A.; Felker, P.; González, C. Correlations between soil and cladode nutrient concentrations and fruit yield and quality in cactus pears, Opuntia ficus-indica in a traditional farm setting in Argentina. Journal of Arid Environments, v.59, p.115-132, 2004. doi:10.1016/j.jaridenv.2004.01.015.

Nardi, S.; Morari, F.; Berti, A.; Tosoni, M.; Giardani, L. Soil organic matter properties after 40 years of different use of organic and mineral fertilisers. European Journal of Agronomy, v.21, p.357-367, 2004.

Novais, R. F.; Alvarez V., V. H.; Barros, N. F.; Fontes, L. E. F.; Neves, J. C. L. (ed.). Fertilidade do solo. 1.ed. Viçosa: Sociedade Brasileira de Ciência do Solo, 2007. 1017p.

Ramos, J. P. de F.; Leite, M. L. de M. V.; Oliveira Júnior, S. de; Nascimento, J. P. do; Santos, E. M. Crescimento vegetativo de Opuntia fícus-indica em diferentes espaçamentos de plantio. Caatinga, v.24, p.41-48, 2011.

Santos, D. C.; Farias, I.; Lira, M. A.; Santos, M. V. F.; Arruda, G. P.; Coelho R. S. B.; Dias, F. M.; Warumby, J. F.; Melo, J. N. Manejo e utilização da palma forrageira (Opuntia e Nopalea) em Pernambuco: Cultivo e utilização. Recife: IPA, 2002. 45p.

Silva, D. J.; Queiroz, A. C. Análise de alimentos: Métodos químicos e biológicos. 3.ed. Viçosa: UFV, 2009. 235p.

Silva, J. A.; Bonomo, P.; Donato, S. L. R.; Pires, A. J. V.; Rosa, R. C. C.; Donato, P. E. R. Composição mineral em cladódios de palma forrageira sob diferentes espaçamentos e adubações química. Revista Brasileira de Ciências Agrárias, v.7, p.866-875, 2012. http://dx.doi.org/10.5039/agraria.v7isa2134

Silva, J. A.; Donato, S. L. R.; Donato, P. E. R.; Souza, E. S.; Padilha Jr, M. C.; Silva Jr, A. A. Extraction/export of nutrients in Opuntia ficus-indica under different spacings and chemical fertilizers. Revista Brasileira de Engenharia Agrícola e Ambiental v.20, p.236242, 2016. doi.org/10.1590/1807-1929/agriambi.v20n3p236-242

Silva, L. M.; Fagundes, J. L.; Viegas, P. A. A.; Muniz, E. N.; Rangel, J. H.; Moreira, A. L.; Backes, A. C. Produtividade da palma forrageira cultivada em diferentes densidades de plantio. Ciência Rural, v.44, p.2064-2071, 2014. http://dx.doi.org/10.1590/0103

Teles, M. M.; Santos, M. V. F.; Dubeux Júnior, J. C. B.; Lira, M. A.; Ferreira, R. L. C.; Bezerra Neto, E. C.; Farias, I. Efeito da adubação e do uso de nematicida na composição química da palma forrageira (Opuntia ficus-indica Mill). Revista Brasileira de Zootecnia, v.33, p.1992-1998, 2004. http://dx.doi.org/10.1590/ S1516-35982004000800010

Zañudo-Hernández, J.; Aranda E. G. C.; Ramírez-Hernández, B. C.; Pimienta-Barrios, E.; Castillo-Cruz, I,; Pimienta-Barrios, E. Ecophysiological responses of Opuntia to water stress under various semi-arid environments. Journal PACD, v.12, p.20-36, 2010. 